\title{
Use of Waste Plastic Char as Adsorbent for Removal of Arsenic and COD from Aqueous Solution
}

\author{
NEELANJAN DUTTA ( $\square$ neel2job@gmail.com ) \\ Indian Institute of Engineering Science and Technology https://orcid.org/0000-0002-3007-5674 \\ Anirban Gupta \\ IIEST Shibpur: Indian Institute of Engineering Science and Technology
}

\section{Research Article}

Keywords: Waste HDPE \& PP, Plastic Char, Characterization, Adsorption. Arsenic and COD Removal

Posted Date: January 17th, 2022

DOI: https://doi.org/10.21203/rs.3.rs-1247280/v1

License: (c) (i) This work is licensed under a Creative Commons Attribution 4.0 International License.

Read Full License 


\title{
Use of Waste Plastic Char as Adsorbent for Removal of Arsenic and COD from Aqueous Solution
}

\author{
Neelanjan Dutta ${ }^{(1)}$, Anirban Gupta ${ }^{(2)}$ \\ ${ }^{1}$ Research Scholar, Department of Civil Engineering, IIEST Shibpur, West Bengal, India \\ ${ }^{2}$ Professor, Department of Civil Engineering, IIEST Shibpur, West Bengal, India
}

(Corresponding Author: Neelanjan Dutta

Email id: neel2job@gmail.com; ORCID:0000-0002-3007-5674)

\begin{abstract}
In present study, the solid char derived from the pyrolysis of waste high-density polyethylene (HDPE) and polypropylene (PP) was tested for removal (adsorption) of inorganic arsenic $\left(\mathrm{As}^{5+}\right)$ and organic matters (COD) from water and wastewater, respectively. It was observed that the solid char could remove $60 \%$ of arsenic $(+5)$ at a dose of $4 \mathrm{gm} / \mathrm{L}$ for a contact time of $30 \mathrm{~min}$ and the COD removal was $50 \%$ at a dose of $4 \mathrm{gm} / \mathrm{L}$ with a contact time of $25 \mathrm{~min}$. In both cases the adsorption data was found to fit better with Langmuir model. The adsorption capacity of mixed plastic char for $\mathrm{As}^{5+}$ was observed to be in the range of $1.45-1.75 \mathrm{mg} / \mathrm{gm}$ and in the range of $60.625-67.9 \mathrm{mg} / \mathrm{gm}$ for COD. Proximate and ultimate analysis indicated that the pyrolytic char had a large quantity of volatile matter (46.50-48.0\%), carbon (41.3-84.7\%), and a small amount of moisture (1.2-2.5\%). The calorific value and density of plastic char were found to be in the range of $13.50-17.50 \mathrm{MJ} / \mathrm{kg}$ and $1.55-1.60 \mathrm{gm} / \mathrm{m}^{3}$. FTIR spectra of mixed HDPE and PP waste pyrolytic oil showed the presence of mostly alkanes and alkenes. It was found that with the increase of pyrolysis temperature, the pore size of solid char increased. The XRD pattern of the plastic chars obtained in this study showed sharp diffraction crystalline peaks. The plastic char can be used for further research for removal of other contaminants from aqueous solution.
\end{abstract}

Keywords: Waste HDPE \& PP; Plastic Char; Characterization; Adsorption; Arsenic and COD Removal.

\section{Introduction}

Plastic pollution is now the biggest concern in the world. UNEP report (2021) confirms that about 300 million tonnes of waste plastics are produced every year. Depending on internal structure and components, the plastic waste materials can take 50 to 500 years or more to complete breakdown (Muller et al., 2001). Plastic waste components have been shown to persist for more than 20 years in landfills (Tansel and Yildiz., 2011). Approximately $78 \%$ of household plastic waste is thermoplastics, composed mainly of high-density polyethylene (HDPE), low-density polyethylene (LDPE), polypropylene (PP), and polystyrene (PS). Polyethylene (PE), which includes HDPE, LDPE, and Linear Low-Density Polyethylene (LLDPE), is the most extensively used plastic raw material in India, accounting for $43 \%$ of total consumption, while PP accounts for $24 \%$. Pyrolysis is a popular thermal recycling method for converting plastic waste into energy in the form of solid, liquid, or gaseous fuels at a temperature ranging from 300-900 ${ }^{\circ} \mathrm{C}$. The use of liquid fuel as an alternative source of energy is well documented in various research papers (Dutta and Gupta., 2021; Sharuddin et al., 2016; Kumar and Singh., 2013). A significant amount of non-condensable gas produced during the pyrolysis process can be used in the industrial combustion process (Jung et al., 2010), or production of power from steam cycles through gas engines and turbines (Fernandez et al., 2011; Hossain \& Davies., 2013). Several researchers (Martín-Lara et al., 2021; Jamradloedluk \& Lertsatitthanakorn., 2014) also used the pyrolytic char as a solid fuel or soil amendment, or as an adsorbent. Several studies compared the properties of various types of biochar derived from the pyrolysis process and found that pyrolysis temperature and feedstock type are crucial factors in determining the effective use of biochar. Still, very few literatures are existing on the use of plastic pyrolytic char for heavy metals removal.

Arsenic (As) has been observed in ground or surface water in many regions of the world (Kobya et al., 2013; Nidheesh \& Singh., 2017). Nearly 108 countries in our world are affected by arsenic pollution in groundwater (Shaji et al., 2020). According to WHO report (2021), in India, arsenic contamination of groundwater beyond the acceptable level has been reported in the states of West Bengal, Jharkhand, Bihar, Uttar Pradesh, Assam, Manipur, and Chhattisgarh (Raessler., 2018). Arsenic exposure in humans from drinking water and food can result in cancer and skin lesions (Hong et al., 2014). Various treatment technologies such as adsorption, coagulation/precipitation, electrocoagulation, adsorption with electrocoagulation, ion exchange, membrane filtration, reverse osmosis have 
been recognized for the arsenic removal from water. But the problems related to higher initial As concentration, varying $\mathrm{pH}$ of source water, maximum amount sludge generation, and making it cost-effective compelled the scientists to research more for developing new technology. On the other hand, through domestic and industrial effluents, different kinds of pollutants, such as organic and inorganic pollutants, were continuously introduced into aquatic environments. Because of these pollutants, a large portion of water streams was discarded as wastewater. COD signifies the amount of oxygen required for total chemical oxidation of oxidizable substances that are organic, inorganic, suspended, or dissolved in the water. Adsorption has recently been regarded as the most effective approach due to the low cost of the process, as well as its easy design and wide range of adsorbent options (Yoshitake et al., 2003; Xu et al., 2002). Activated alumina, fly ash, pyrite fines, manganese greensand, amino-functionalized mesoporous silicas, aluminium loaded Shirasu-zeolite, biochar, and other zeolites have been investigated (Kim et al., 2004; Goswami \& Das, 2000; Subramanian et al., 1997; Bilici Baskan \& Pala, 2011) as adsorbent materials. However, developing affordable and widely available adsorbents remains a major challenge. Adsorption has been extensively used in wastewater treatment to remove organic pollutants and heavy metals (Devi and Dahiya, 2010; Parande et al., 2009). Despite some drawbacks, such as hygroscopicity and poreblocking, carbon materials have long been regarded as an ideal adsorbent due to their low cost. Martin -Lara et al. (2021) carried out research using a waste mixture of polypropylene (PP), polystyrene (PS), and polyethylene film (PE) and observed that pyrolysis temperature has a great impact on the yield of solid products. With the increase of pyrolysis temperature, the adsorption capacity of solid char obtained from the pyrolysis process also increases reaching a maximum of $7.91 \mathrm{mg} / \mathrm{g}$ at $550{ }^{\circ} \mathrm{C}$. Singh et al., (2020) was conducted an experiment for adsorbing arsenic by plastic char derived from pyrolysis of waste Polyvinyl chloride (PVC), Polyethylene terephthalate (PET), and Polyethylene (PE). Among all the plastic char's tests performed, PE and PVC mixed char had maximum As removal rate, ranging from 71.6 to $99.4 \%$, and PE and PET chars showed the lowest amount of sorption ranging from 12.4 to $32.5 \%$. Jamradloedluk and Lertsatitthanakorn (2013) found that the plastic char obtained from HDPE waste plastic pyrolysis had a BET surface area, pore-volume, and pore size of $16.77 \mathrm{~m}^{2} / \mathrm{gm}$, $0.2080 \mathrm{~cm}^{3} / \mathrm{gm}$, and $496 \AA$, respectively. Though biochar has been widely used effectively by several researchers for COD removal (Khurshid et al., 2021; Sanou et al., 2017; Hata et al., 2016), the application of solid char in water treatment technologies was not tried by most researchers. The use of plastic char for the organic and inorganic matter removal in water treatment demands further research for use of char as a valuable resource and upscaling the technology more effectively.

The current research mainly concentrated on the use of waste plastic char derived from HDPE and PP pyrolysis as a low-cost and carbonaceous material for As and COD removal, as inferred by pyrolysis of plastic waste. Although a variety of sorbents have been used to remove As and COD from polluted sites, the use of chars derived from waste plastics is a new matter of concern. Furthermore, this is extremely beneficial because solving the problems of managing plastic waste and utilizing existing resources to adsorb heavy metals and organic pollutants. Batch adsorption equilibrium experiments were conducted to determine the optimal conditions for As and COD removal. The predominant mechanisms and sorption efficiency of the plastic char also reveal that it can be used effectively on larger scales for the removal of other heavy metals or organic pollutants.

\section{Material and Methods}

\subsection{Feedstock}

Plastic char samples were prepared using waste HDPE and PP as feedstock. The waste plastics of HDPE and PP were collected from the local dumping site. All the plastics were then washed with distilled water and dried in the oven for 24 hours. After that, the moisture-free plastic samples were grinded prior to pyrolysis. The proximate and ultimate characteristics of waste HDPE and PP samples are presented in Table 1.

\subsection{Plastic char Preparation}

The pyrolysis of waste HDPE and PP was conducted using a laboratory-scale batch reactor comprising of a condenser, and liquid collector (Fig. 1) at $400{ }^{\circ} \mathrm{C}, 425^{\circ} \mathrm{C}, 450{ }^{\circ} \mathrm{C}, 475{ }^{\circ} \mathrm{C}$, and $500{ }^{\circ} \mathrm{C}$ under a heating rate of 14 ${ }^{\circ} \mathrm{C} / \mathrm{min}$. In each run, $100 \mathrm{~g}$ of feedstock (HDPE: $\mathrm{PP}=1: 1$ ) was taken inside the reactor. After that, the collected plastic char was sieved to achieve $0.5-1.0 \mathrm{~mm}$ in size (Fig. 2). Finally, the chars (in form of pellets) were ovendried for 24 hours at $105{ }^{\circ} \mathrm{C}$ and kept in a vacuum desiccator for further use as an adsorbent. 


\subsection{Plastic char Characterization}

Physical properties such as calorific value, moisture content, density were measured for the solid char derived from pyrolysis of virgin HDPE and PP samples. The elemental composition of the char was characterized using a CHNS analyzer. The plastic chars derived from pyrolysis at different temperatures $\left(400{ }^{\circ} \mathrm{C}, 450{ }^{\circ} \mathrm{C}\right.$, and $\left.500{ }^{\circ} \mathrm{C}\right)$ were characterized by Scanning Electron Microscopy (SEM) (Model: JSM-IT200, JEOL) to determine the surface topography and X-Ray Diffraction (XRD) study (Model: PANalytical X-PERT PRO) was performed to determine the crystallographic structure of the material. Calorific value was determined by using a bomb calorimeter (Manufacturer: Mohan Brothers) as per ASTM D 5865. The Brunauer-Emmett-Teller (BET) surface area was determined by the Autosorb-analyzer, Quanta Chrome. Solid char samples were mixed with spectroscopic grade dried $\mathrm{KBr}$ and compressed into pellets to obtain FTIR absorption spectra. FTIR spectra were recorded between the wavenumber of $4000 \mathrm{~cm}^{-1}$ and $400 \mathrm{~cm}^{-1}$ with a resolution of $4 \mathrm{~cm}^{-1}$. Prior to FTIR analyses, all solid char samples and $\mathrm{KBr}$ were oven-dried overnight at $60^{\circ} \mathrm{C}$.

Table 1: Proximate and Ultimate analysis for waste HDPE and PP samples

\begin{tabular}{|c|c|c|}
\hline Properties & $\begin{array}{c}\text { Waste HDPE Sample } \\
\text { (Taking average of 3 replicated } \\
\text { experiments) } \\
\text { Proximate Analysis }\end{array}$ & $\begin{array}{c}\text { Waste PP Sample } \\
\text { (Taking average of 3 replicated } \\
\text { experiments) }\end{array}$ \\
\hline Moisture Content (\%) & 1.56 & 1.65 \\
\hline Volatile Matter (\%) & 89.25 & 88.25 \\
\hline Fixed Carbon (\%) & 1.3 & 4.9 \\
\hline Ash Content (\%) & 4.65 & 76.70 \\
\hline Ultimate Analysis & $12.84 \%$ \\
\hline Hydrogen (\%) & 78.20 & 0.32 \\
\hline Nitrogen (\%) & 12.875 & $<0.1$ \\
\hline Sulphur (\%) & 0.375 & \\
\hline
\end{tabular}

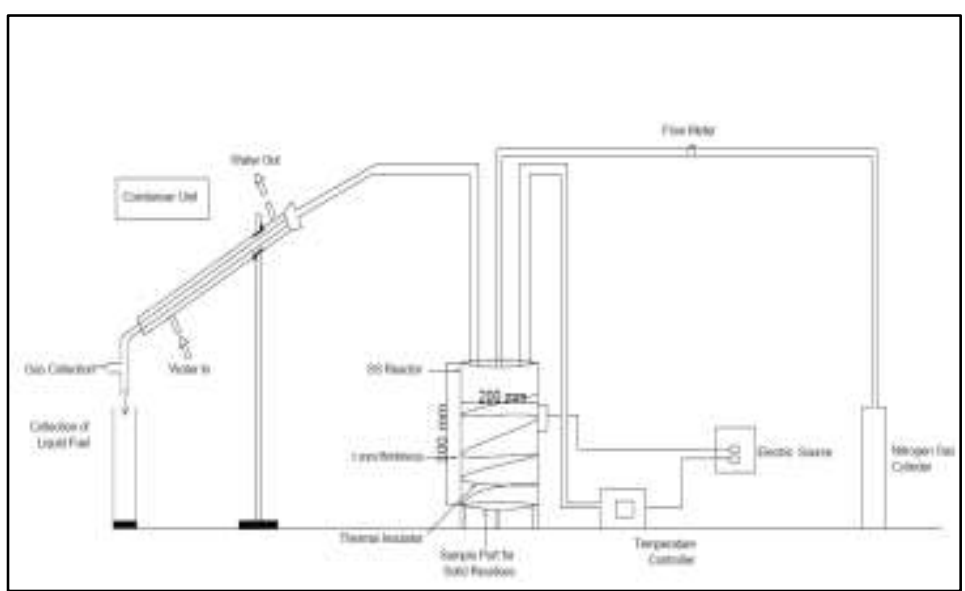

Fig. 1: Experimental batch reactor setup for the pyrolysis process

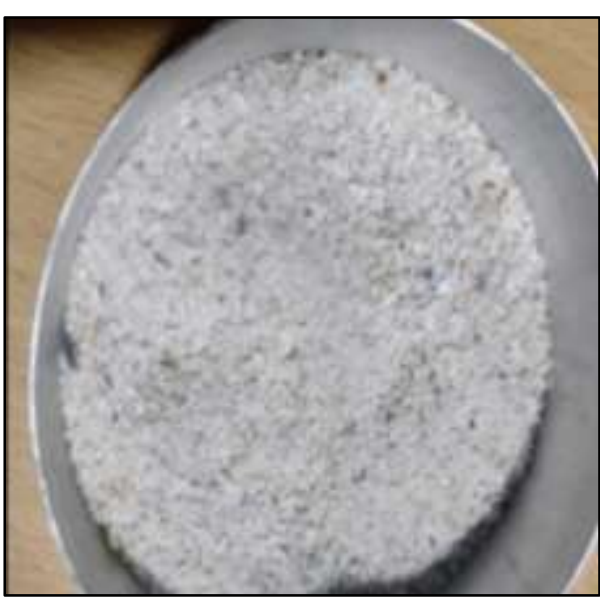

Fig. 2: Plastic char

\subsection{Chemical Analysis of Aqueous Samples}


Parameters of water and wastewater samples like turbidity, $\mathrm{pH}$, chloride, TDS, Alkalinity, hardness, iron were analyzed by following the standard procedures. Arsenic content was measured by SDDC spectrophotometric method (APHA, 1992). COD was determined by the open reflux method. The adsorption studies were carried out with the char derived from pyrolysis of mixed (HDPE:PP as 1:1) plastic to remove arsenic and COD from water and wastewater, respectively. Stock sodium arsenate solution of $100 \mathrm{mg} / \mathrm{L}$ of $\mathrm{As}^{5+}$ was prepared for the experiments. From this arsenic stock solution, $10 \mathrm{mg} / \mathrm{L}$ of the working arsenic solution was prepared which was used for the adsorption experiments. All the solutions were prepared using NIT Sikkim tap water. The $\mathrm{pH}$ of the $\mathrm{As}^{5+}$-spiked water was adjusted to 7.0 by the addition of sodium hydroxide $(\mathrm{NaOH})$.

\subsection{Arsenic Sorption Kinetics}

The uptake capacity of the plastic chars to adsorb $\mathrm{As}^{5+}$ and organic matter was analyzed by Langmuir and Freundlich isotherms. The Langmuir model is based on the assumption that the adsorbent has a fixed amount of adsorption sites and that sorption on the adsorbent surface is a monolayer. The Freundlich model, on the other side, assumes that the adsorbent surface is heterogeneous and that sorption on it is multilayer.

Langmuir model is represented as:

$\mathrm{q}_{\mathrm{e}}=\frac{C_{e} K_{a} q_{m}}{1+C_{e} k_{a}}$

The Langmuir isotherm can be expressed in linear form as:

$\frac{C_{e}}{q_{e}}=\left(\frac{1}{q_{m}}\right) \mathrm{C}_{\mathrm{e}}+\frac{1}{K_{a} q_{m}}$

where $q_{m}$ is the monolayer sorption saturation capacity $(\mathrm{mg} / \mathrm{g})$ and $K_{a}$ represents the enthalpy of sorption $(\mathrm{L} / \mathrm{mg})$

On the other hand, the Freundlich isotherm is showed as:

$q_{e}=K_{f} C_{e}^{1 / n}$

and also, in the linearized form:

$\ln q_{e}=\ln K_{f}+1 / n \ln C_{e}$

where $C_{e}$ is the equilibrium concentration $(\mathrm{mg} / \mathrm{L}), q_{e}$ is the amount of adsorbate adsorbed $(\mathrm{mg} / \mathrm{g})$, and $K_{f}$ and $n$ are Freundlich constants.

A kinetic study was conducted to find out the required to attain the equilibrium condition. To conduct the kinetic study, $4 \mathrm{gm} / \mathrm{L}$ of mixed plastic pyrolysis char was contacted with $10 \mathrm{mg} / \mathrm{L}$ of As ${ }^{5+}$ solution or wastewater solution in an Erlenmeyer flask for different contact times of 5-35 min. The flasks were put in a horizontal shaker and after the period of contact, the suspensions were filtered through a $0.45-\mu \mathrm{m}$ filter before analysing for remaining $\mathrm{As}^{5+}$ or COD content. For the isotherm adsorption study, a similar procedure was followed with varying doses of adsorbent (pyrolysis char) and was contacted for a period equal to the equilibrium adsorption times obtained from the kinetic studies.

\section{Results and Discussion}

\subsection{Effect of Temperature on Yield of Char}

Temperature is the most important operating parameter in pyrolysis because it controls the cracking process of the polymer chain. The van der Waals force attracts molecules together, which prevents them from collapsing. When the temperature of a system rises, the vibration of molecules within the system rises, and molecules tend to evaporate away from the object's surface. The carbon chains break when the energy induced by the van der Waals force along the polymer chains exceeds the enthalpy of the $\mathrm{C}-\mathrm{C}$ bonds in the chain (Sobko, 2008). Thermal pyrolysis is an endothermic process, i.e., a significant amount of heat is required to bring the feedstock to the reaction temperature. During pyrolysis, polymer materials were heated to high temperatures, and their macromolecules were broken down into smaller molecules, yielding a wide range of hydrocarbons. For the current study, $100 \mathrm{gm}$ of mixed waste (HDPE:PP= 1:1) sample was taken for the pyrolysis process using the laboratory- 
scale batch reactor, at temperatures of $400{ }^{\circ} \mathrm{C}, 425{ }^{\circ} \mathrm{C}, 450{ }^{\circ} \mathrm{C}, 475{ }^{\circ} \mathrm{C}$, and $500{ }^{\circ} \mathrm{C}$ under a heating rate of 14 ${ }^{\circ} \mathrm{C} / \mathrm{min}$. The liquid, gas, and solid char yield is shown in Fig. 3A, 3B, and $3 \mathrm{C}$ by taking the average of three replicate experiments with an error bar (using standard deviation). From Fig. 3A, it was observed that the maximum amount of liquid (60\%) was yielded at $475{ }^{\circ} \mathrm{C}$, and then, the liquid yield decreased with the increase of temperature up to $500{ }^{\circ} \mathrm{C}$. The same trend was also observed for thermal pyrolysis of virgin HDPE and PP in another study which was conducted by the author (Dutta \& Gupta, 2021). The yield of solid char decreased from $27 \%$ to $12.67 \%$ at temperatures of 400 and $500{ }^{\circ} \mathrm{C}(3 \mathrm{C})$.

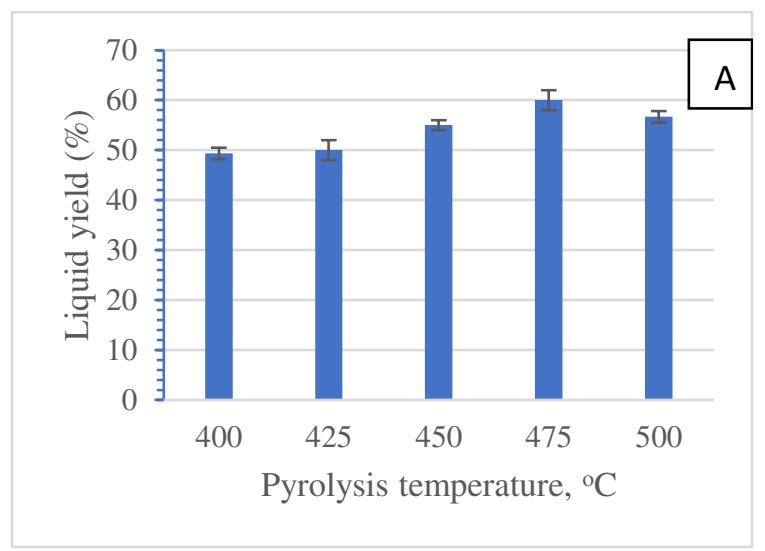

Fig. 3A: Yield of liquid for pyrolysis of mixed waste HDPE and PP

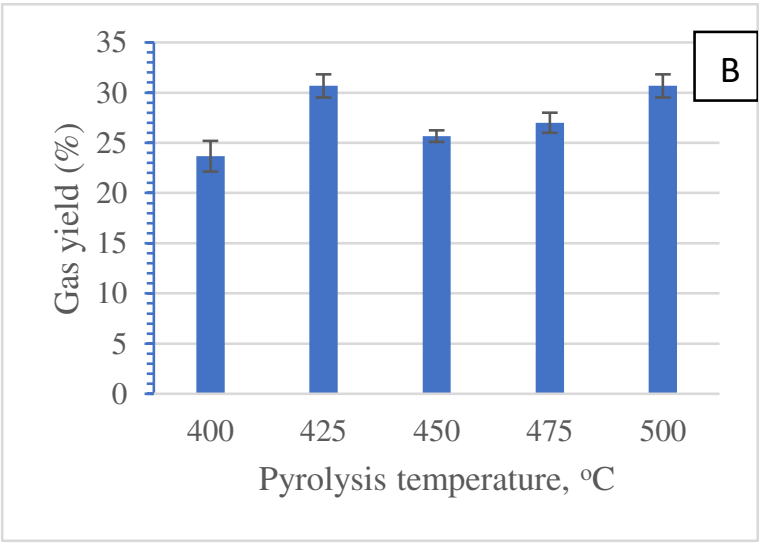

Fig. 3B: Yield of gas for pyrolysis of mixed waste HDPE and PP

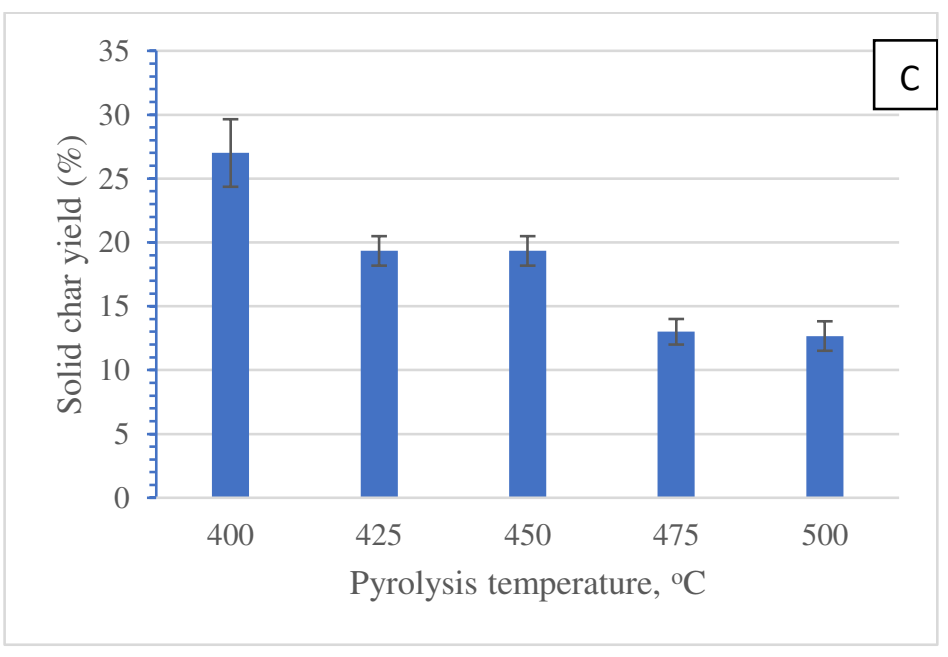

Fig. 3C: Yield of solid char for pyrolysis of mixed waste HDPE and PP 


\subsection{SEM and XRD Analysis of Plastic Char}

The SEM analysis method involves for the examination of changes in material morphology at the micro-scale. Each sample (P1, P2 \& P3) was depicted at 1000X, and $5000 \mathrm{X}$ magnifications (Fig. 4A to Fig. 4C). The plastic char samples showed significant changes in the structure when it was prepared at different temperatures (400 to $\left.500{ }^{\circ} \mathrm{C}\right)$. The SEM images of plastic char showed rough morphology and undefined geometry, which was in alignment with the findings of other studies on plastic char (Singh et al., 2020; Singh et al., 2021; Jamradloedluk and Lertsatitthanakorn, 2013). It was noticed that the surface texture of char became rougher and more porous when either the operating temperature or the residence time ( $25 \mathrm{~min}$ to $35 \mathrm{~min}$ ) was increased. At $400{ }^{\circ} \mathrm{C}$, the sample had a relatively flat surface without clear visible pores. Chars obtained at lower temperatures showed relatively smooth surfaces with tubular shapes. Raising the temperature to $500{ }^{\circ} \mathrm{C}$ effectively changed the surface morphology and more pores were observed. The surface structure of the material had lost its smoothness and cracks were evident. Increase of the surface area and pore volume of the solid char material till a maximum temperature due to devolatilization of some biomass components was also reported earlier (Angin et al., 2014; Brunson et al., 2014); however, changes in surface characteristics were also related to other factors such as the feedstock source, experimental conditions, equipment used. Due to the accumulation of charge on the surface of P3 char, a slightly blurred image was formed. Similar blur images caused by charge accumulation were observed in an earlier study conducted by Singh et al., 2020.
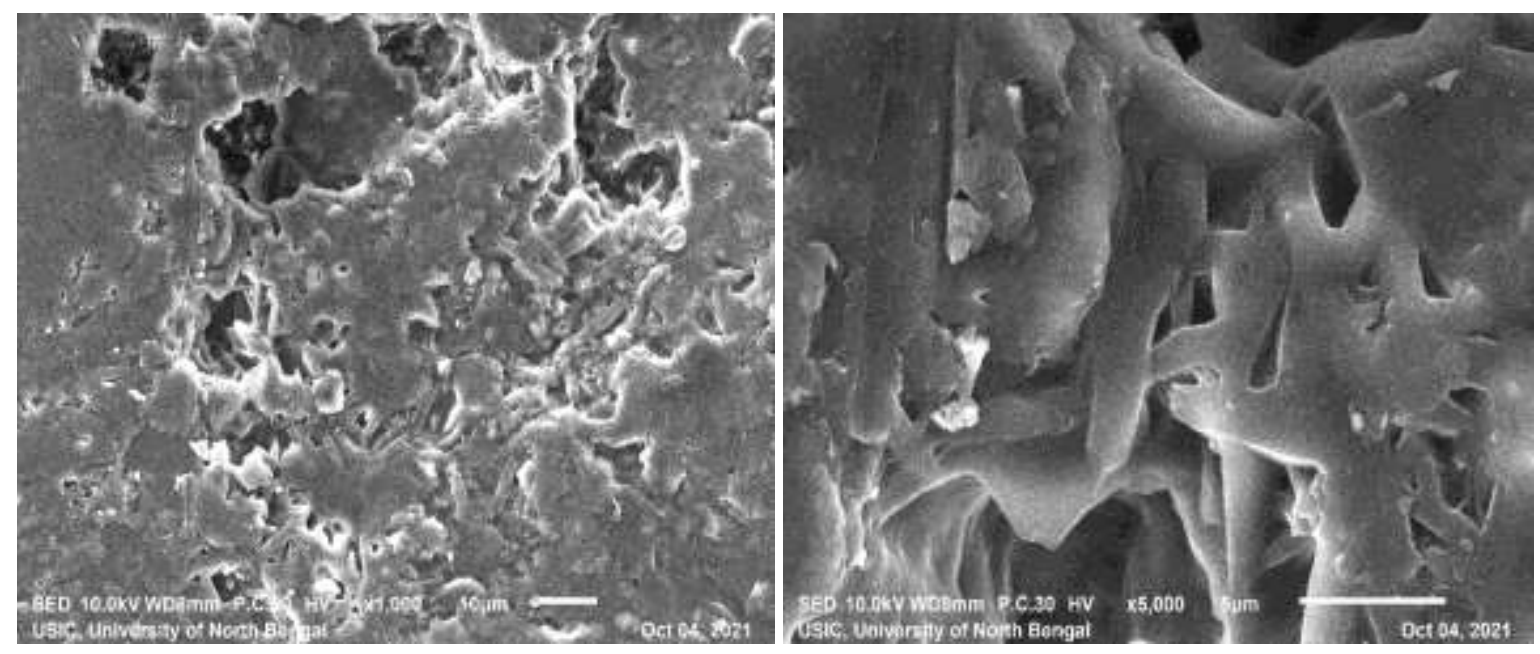

Fig. 4A: SEM images of plastic char prepared at $400{ }^{\circ} \mathrm{C}(\mathrm{P} 1)$
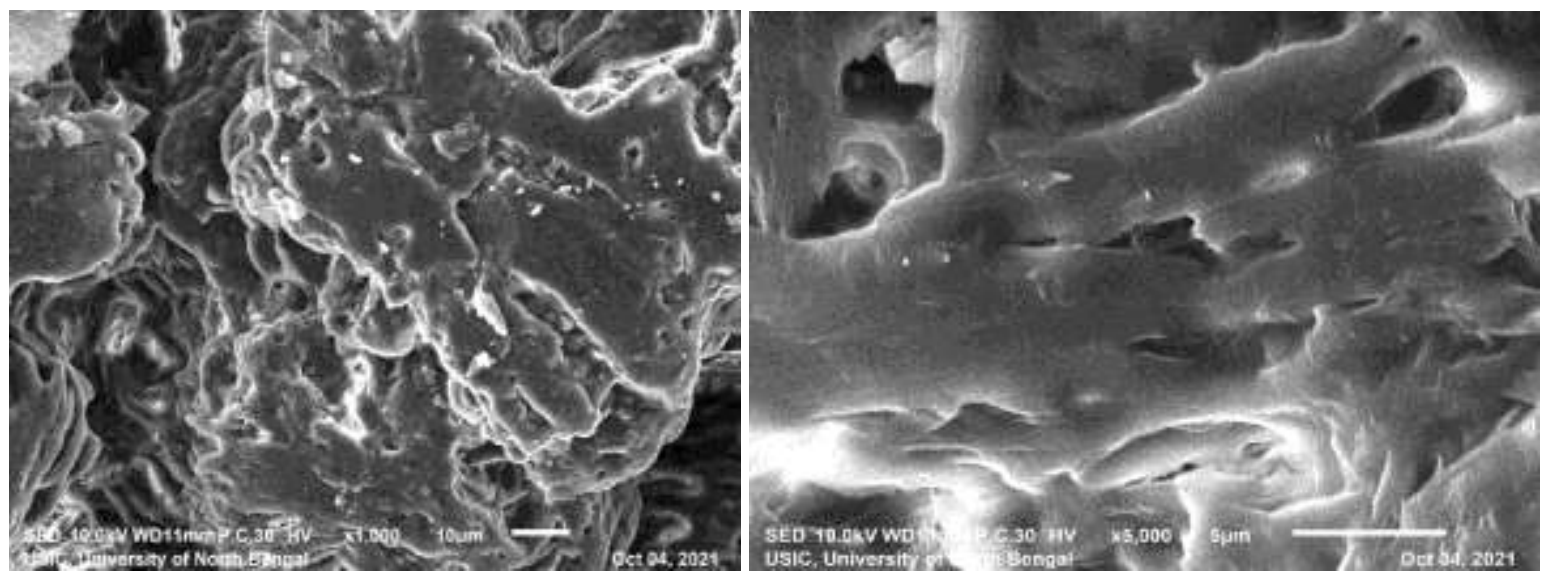

Fig. 4B: SEM images of plastic char prepared at $450{ }^{\circ} \mathrm{C}(\mathrm{P} 2)$ 

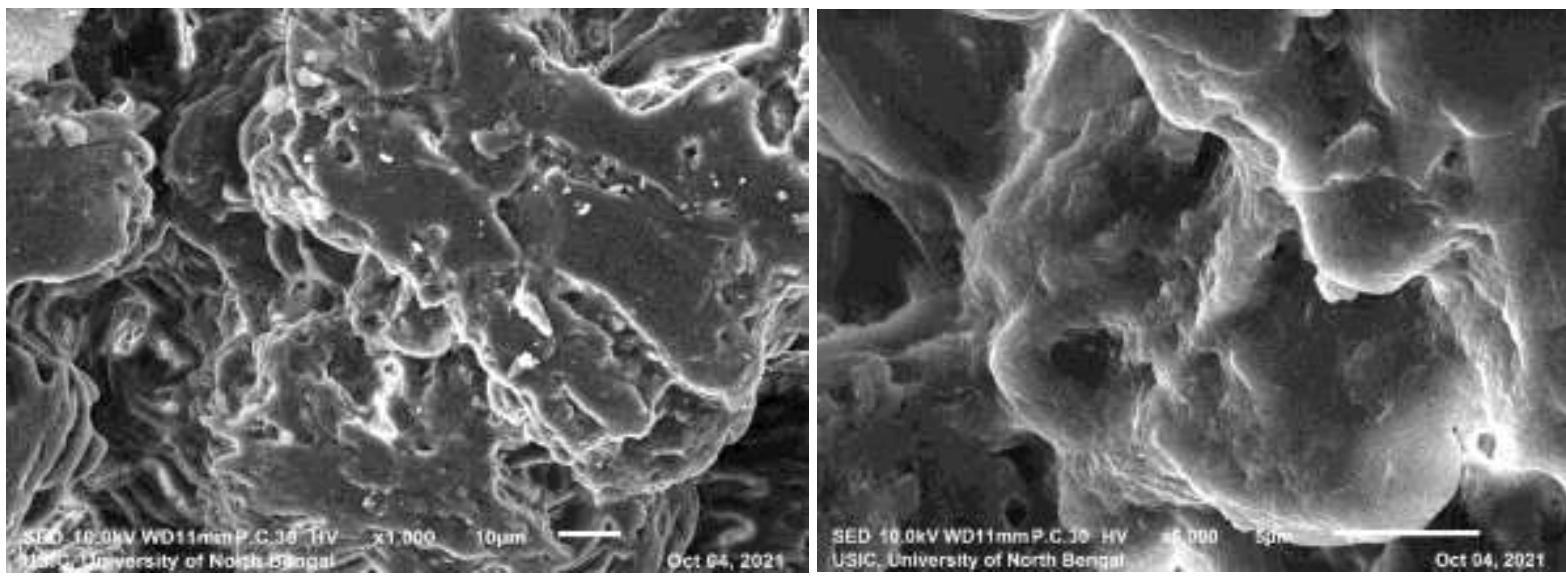

Fig. 4C: SEM images of plastic char prepared at $500{ }^{\circ} \mathrm{C}(\mathrm{P} 3)$

The XRD pattern of the plastic chars (P1, P2, \& P3) obtained in this study showed sharp diffraction crystalline peaks. In the case of $\mathrm{P} 1$, the spectrum showed strong peaks at around $14.11^{0}, 16.79^{0}, 18.57^{0}, 21.5^{0}$, and $23.85^{\circ}$, while for P2 at $14.19^{0}, 17.02^{0}, 18.63^{\circ}, 21.71^{\circ}$, and $24.02^{\circ}$ and for $\mathrm{P} 3$ at $14.11^{0}, 16.93^{\circ}, 18.55^{\circ}, 21.47^{\circ}$, and $23.77^{\circ}$ (Fig. 5A, Fig. 5B, and Fig. 5C). Higher counts of the peak were observed at higher temperatures indicating that an increase of temperature increased the crystallinity of solid char.

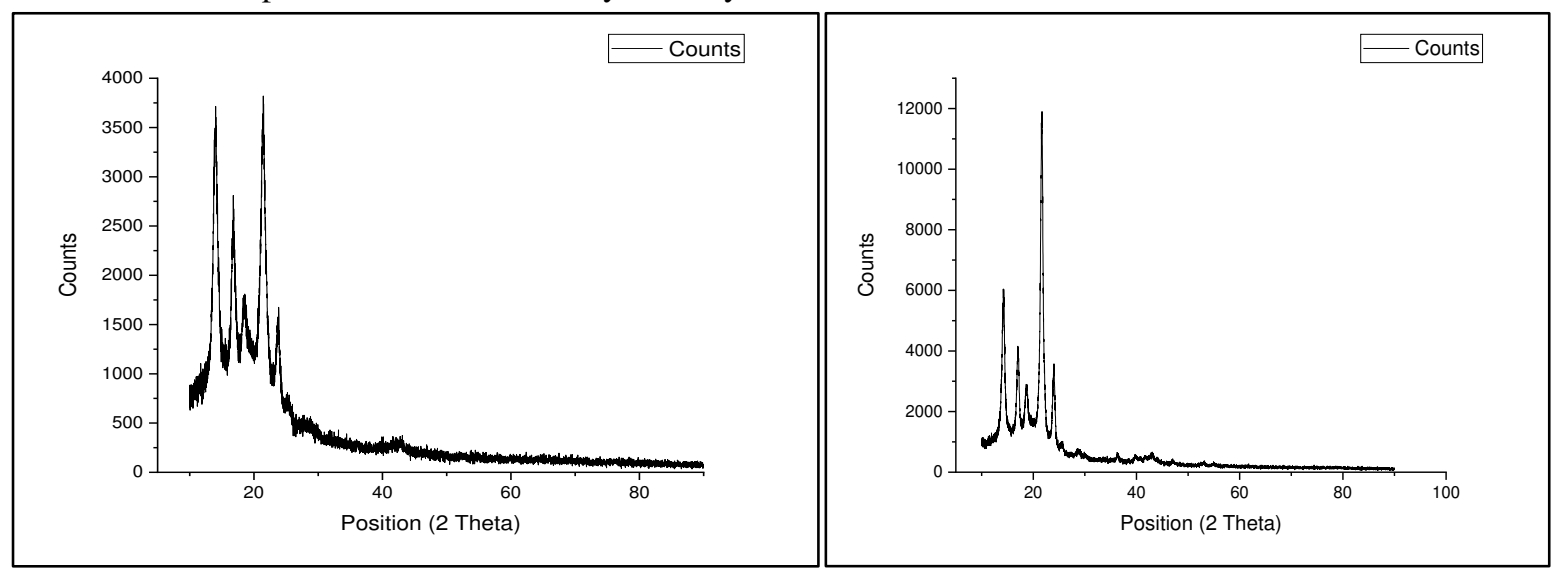

Fig. 5A: XRD image of plastic char prepared at $400{ }^{\circ} \mathrm{C}(\mathrm{P} 1)$ Fig. $5 \mathrm{~B}$ : XRD image of plastic char prepared at 450 ${ }^{0} \mathrm{C}(\mathrm{P} 2)$

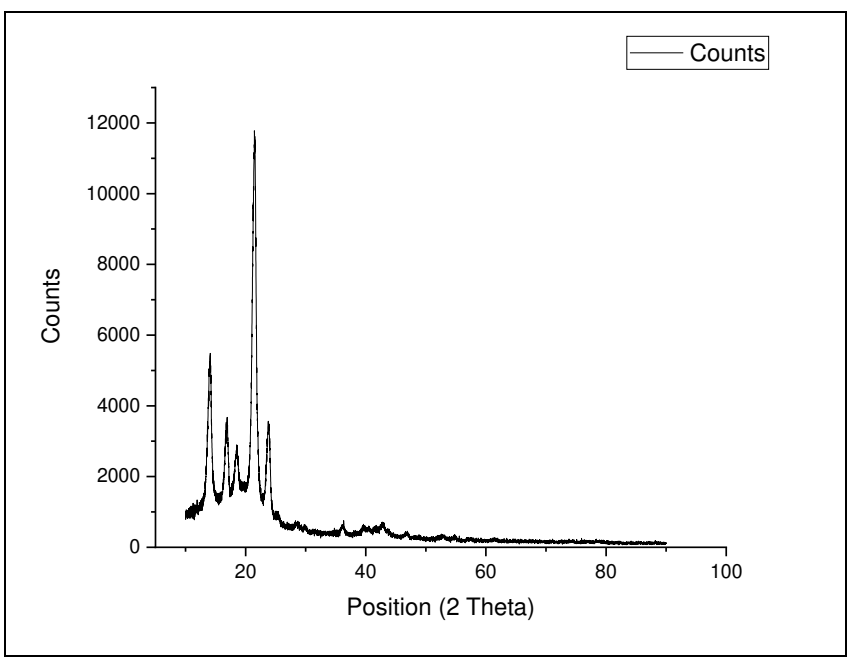

Fig. 5C: XRD image of plastic char prepared at $500{ }^{\circ} \mathrm{C}(\mathrm{P} 3)$ 


\subsection{Properties of Pyrolytic Char}

It was found that with the increase of pyrolysis temperature ( 400 to $500{ }^{\circ} \mathrm{C}$ ), the pore size of solid char increased (4.7-4.9 to 6-6.5 nm). Therefore, the solid char obtained from the waste plastic pyrolysis at $500{ }^{\circ} \mathrm{C}$ was used for the adsorption study. The obtained char possesses a good calorific value $(13.50-17.50 \mathrm{MJ} / \mathrm{kg})$, volatile matter (46.50-48.0\%), and is rich in $\mathrm{C}(41.3-84.7 \%)$, while $\mathrm{N}$ and $\mathrm{H}$ contents of $0.10-2.78 \%$ and $1.83-5.17 \%$ were relatively low. This was consistent with the characteristics of the chars previously derived by Fang et al., (2016). Proximate analysis of waste plastic char showed less moisture content. Some studies also stated that char obtained at low temperature $\left(300-500^{\circ} \mathrm{C}\right)$ for metal removal is more favourable than char derived from pyrolysis at a higher temperature $\left(700-900^{\circ} \mathrm{C}\right.$ ). Various Properties of the char (derived at $500{ }^{\circ} \mathrm{C}$ ) is presented in Table 2.

Table 2: Properties of mixed waste plastics (HDPE and PP) pyrolysis char (P3) prepared at $500{ }^{\circ} \mathrm{C}$

\begin{tabular}{|c|c|}
\hline Properties & Experimental Values \\
\hline Calorific value & $13.50-17.50 \mathrm{MJ} / \mathrm{kg}$ \\
\hline Carbon & $41.3-84.7 \%$ \\
\hline Nitrogen & $0.10-2.78 \%$ \\
\hline Hydrogen & $1.83-5.17 \%$ \\
\hline Moisture content & $1.2-2.5 \%$ \\
\hline Density & $1.55-1.60 \mathrm{gm} / \mathrm{m}^{3}$ \\
\hline BET surface area & $10.5-12.8 \mathrm{~m}^{2} / \mathrm{g}$ \\
\hline Pore size & $6-6.5 \mathrm{~nm}$ \\
\hline
\end{tabular}

\subsection{FTIR Analysis of Plastic Char}

FTIR analysis was performed to characterize various functional groups on the surface of plastic char (Fig. 6). FTIR spectroscopy is used extensively for material characterization in the plastics industry. Results revealed that the surface chemistry of plastic char is largely varied with an increase in pyrolysis temperature. Alkanes are identified by absorptions because of $\mathrm{C}-\mathrm{H}$ bending at $1470-1450 \mathrm{~cm}^{-1}$. The stretching vibration of the $\mathrm{C}=\mathrm{C}$ bond typically produces a moderate band in the range $1680-1640 \mathrm{~cm}^{-1}$. The strongest bands in the spectra of alkenes in the region $1000-650 \mathrm{~cm}^{-1}$ are those attributed to the carbon-hydrogen bending vibrations of the $=\mathrm{C}-\mathrm{H}$ group. The $-\mathrm{C} \equiv \mathrm{C}-$ stretch appears as a weak band from 2260-2100 $\mathrm{cm}^{-1}$. Indeed, the peaks at $873 \mathrm{~cm}^{-1}$ and $713 \mathrm{~cm}^{-1}$ indicate $\mathrm{CO}_{3}$ presence (Djebaili et al., 2015). The peak at $1423 \mathrm{~cm}^{-1}$ denotes the presence of $\mathrm{C}=\mathrm{O}$ and $\mathrm{O}-\mathrm{H}$ bonds (Pereira et al., 2017); though, it may also indicate the existence of C-O-O stretches in the char (Kumar et al., 2018). The peak at $1030 \mathrm{~cm}^{-1}$ indicates the presence of kaolin in char. The peak at $1241 \mathrm{~cm}^{-1}$ represents the existence of amines in the plastic char (Tang et al., 2018), with the weak peak at $1576 \mathrm{~cm}^{-1}$ also showing the presence of amides. The presence of aliphatic ether C-O or alcoholic C-O is indicated by the peak at $1091 \mathrm{~cm}^{-1}$, although Si-O-Si bonds in the char could also be present (Claoston et al., 2014). A strong peak at $905.415 \mathrm{~cm}^{-1}$ and $717.39 \mathrm{~cm}^{-1}$ denotes the $\mathrm{C}-\mathrm{H}$ bending. The other peaks of higher intensity identified around $1020 \mathrm{~cm}^{-1}$ and $870 \mathrm{~cm}^{-1}$ correspond to the vibrations of the $\mathrm{C}-\mathrm{H}$ bonds of aromatic rings. Carboxylic groups consist of $\mathrm{C}=\mathrm{O}$ and can be found at 1749-1728 $\mathrm{cm}^{-1}$. Lactones can be detected by peaks near $1610 \mathrm{~cm}^{-1}$ (Shen et al., 2018). A medium peak appearance at the region 3700-3584 $\mathrm{cm}^{-1}$ corresponds to O-H stretching also showing the presence of either alcohol or phenol. 


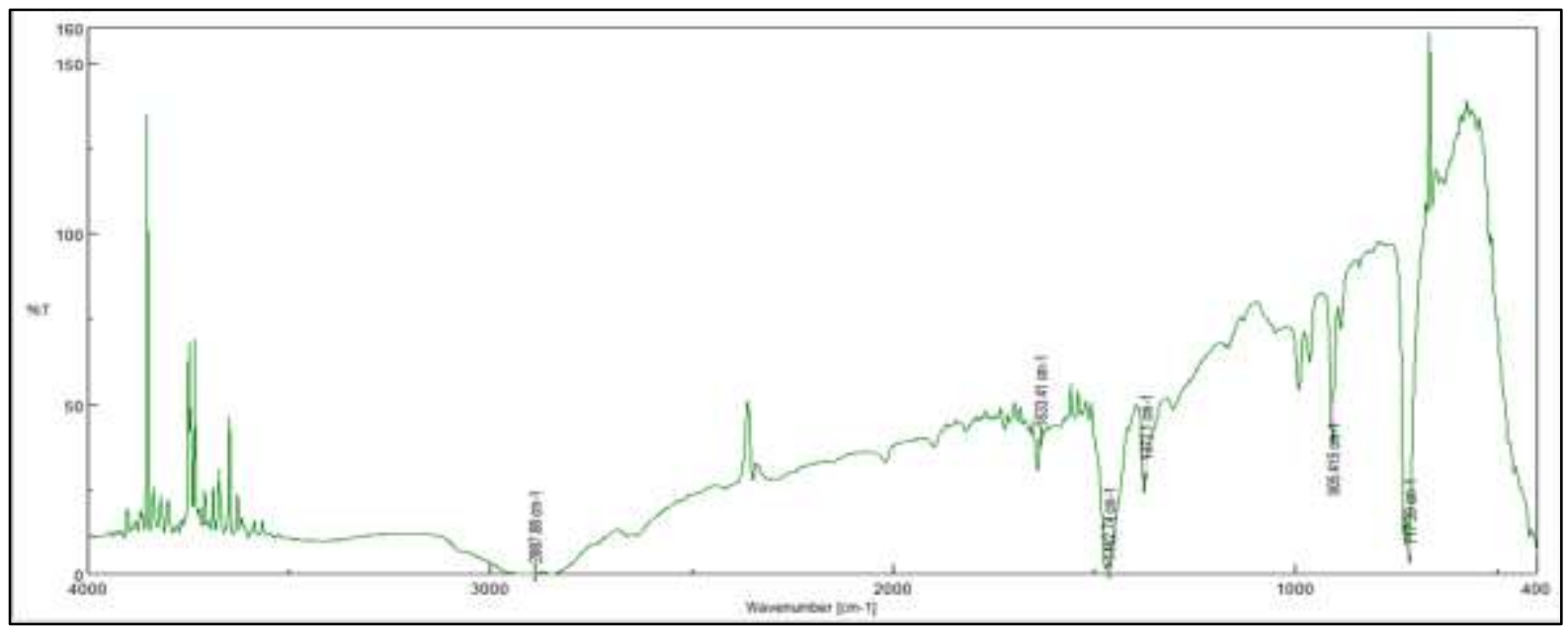

Fig. 6: FTIR spectroscopy of mixed waste plastic (HDPE \& PP) pyrolysis char (P3) prepared at $500{ }^{\circ} \mathrm{C}$

\subsection{Use of solid char as Adsorbent}

The solid char obtained from the pyrolysis process was tested for organic matter (COD) removal from wastewater and inorganic matter (arsenic) removal from an aqueous solution by adsorption onto the char. Batch adsorption tests were conducted to study the adsorption of $\mathrm{As}^{5+}$ onto mixed plastic pyrolysis char. Laboratory tap water of NIT Sikkim (characteristics presented in Table 3) was spiked with $\mathrm{As}^{5+}\left(\mathrm{Na}_{3} \mathrm{AsO}_{4}\right)$ for use in the adsorption study. The water was having low TDS, hardness, and alkalinity with mildly acidic pH. Several researchers (Dutta et al., 2021; Sumathi and Alagamuthu., 2014; Ramaswami et al., 2000) reported that the highest removal efficiency for arsenic was observed at $\mathrm{pH}$ 7. Therefore, the $\mathrm{pH}$ of the $\mathrm{As}^{5+}$-spiked water was adjusted to 7.0 by the addition of sodium hydroxide $(\mathrm{NaOH})$. For the adsorption kinetic tests, char (size $3-4 \mathrm{~mm}$ ) obtained from pyrolysis at 500 ${ }^{\circ} \mathrm{C}(\mathrm{P} 3)$ was taken $(4.0 \mathrm{gm} / \mathrm{L})$ and put in $\mathrm{As}^{5+}$-spiked $(10 \mathrm{mg} / \mathrm{L})$ water and shaken for different contact times $(5-$ $35 \mathrm{~min}$ ). Arsenic adsorption was found to increase with time and beyond $30 \mathrm{~min}$ of contact time, the incremental increase in adsorption was insignificant (Fig. 7). Therefore, the time of equilibrium was considered to be $30 \mathrm{~min}$ and $\mathrm{As}^{5+}$ removal of $60 \%$ was observed. After the equilibrium time, the remaining vacant surface sites are difficult to be occupied by the adsorbate molecules because of repulsive forces between the adsorbate molecules on the solid and bulk phases (Kannan et al. 2010; Das and Mondal, 2011). Isotherm adsorption study was also conducted by varying the dose of mixed plastic pyrolysis char (P3) from 2.0 to $4.50 \mathrm{gm} / \mathrm{L}$ in a $10 \mathrm{mg} / \mathrm{L}$ solution of $\mathrm{As}^{5+}$ keeping the contact time uniform as $30 \mathrm{~min}$ (equilibrium time). Arsenic removal by waste plastic char was observed to vary from 35 to $58 \%$ (Fig. 8 ).

Table 3: Characteristics of Tap Water, NIT Sikkim

\begin{tabular}{|c|c|}
\hline Parameters & Values \\
\hline $\mathrm{pH}$ & $6.5-6.7$ \\
\hline Iron $(\mathrm{mg} / \mathrm{l})$ & 0.00 \\
\hline Arsenic & 0.00 \\
\hline TDS (mg/l) & $20-30$ \\
\hline Chloride (mg/l) & $15-25$ \\
\hline Hardness (mg/l as CaCO 3$)$ & $10-20$ \\
\hline Alkalinity (mg/l as CaCO 3 ) & $25-30$ \\
\hline Turbidity (NTU) & 0 \\
\hline
\end{tabular}




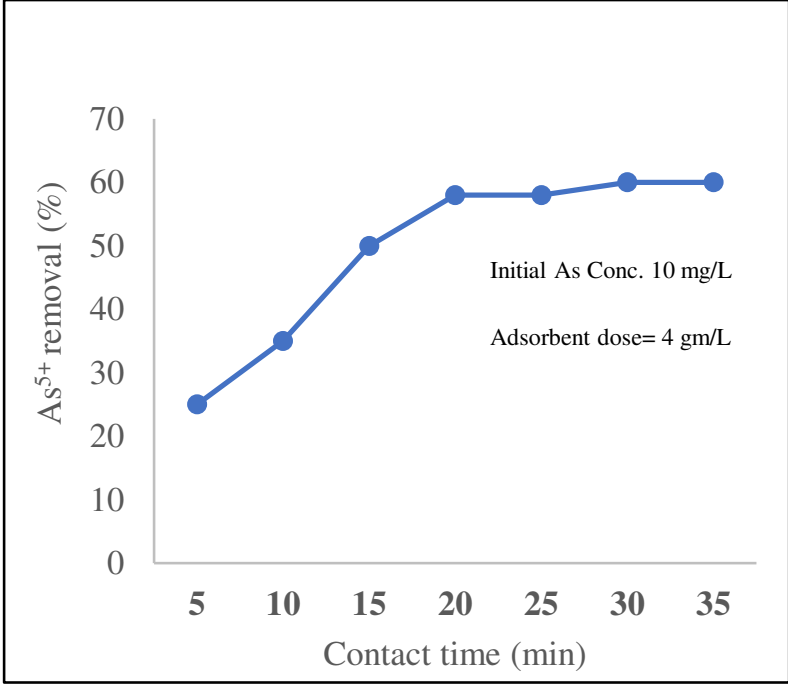

Fig. 7: Removal of arsenic for variation of contact time

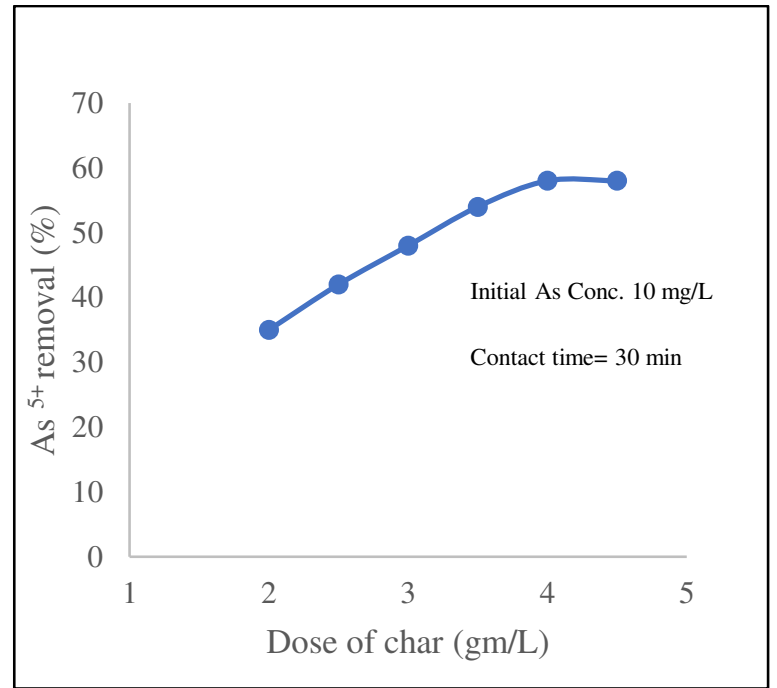

Fig. 8: Removal of arsenic for varying doses of char

The experimental data fitted well for both isotherm models and better fit was obtained for Langmuir isotherm $\left(\mathrm{R}^{2}=0.9953\right)$ in comparison to Freundlich isotherm $\left(\mathrm{R}^{2}=0.9849\right)($ Fig. 9 and Fig. 10).

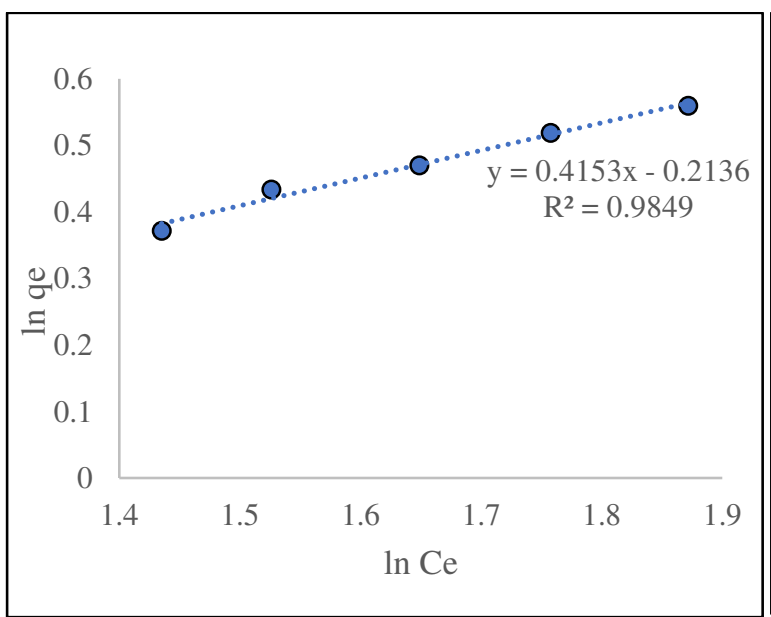

Fig. 9: Linearized plot for Freundlich isotherm for As removal

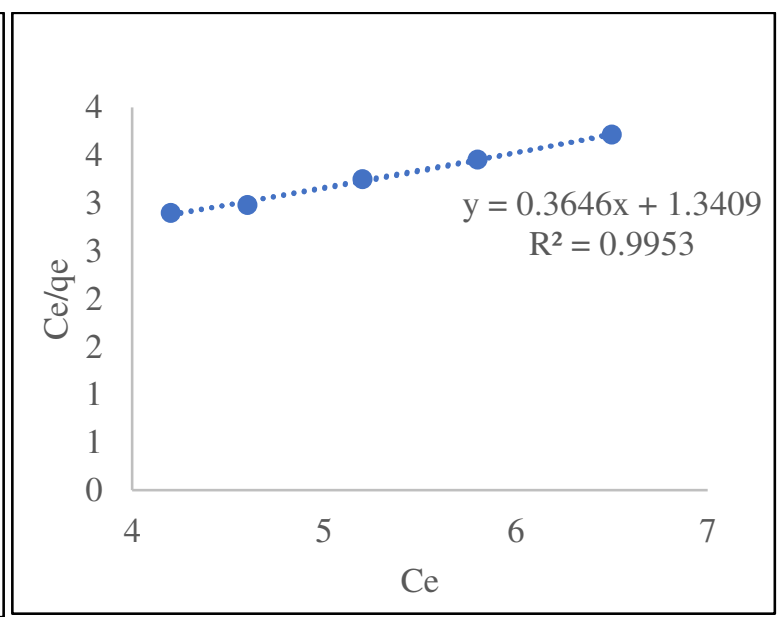

Fig. 10: Linearized plot for Langmuir isotherm for

\section{As removal}

From the linearised plot of Langmuir isotherm (Fig. 10), $\mathrm{K}_{\mathrm{a}}$ and $\mathrm{q}_{\mathrm{m}}$ values were found 0.596 and 2.141 , respectively. The Langmuir isotherm equation can be expressed as:

$\mathrm{q}_{\mathrm{e}}=\frac{1.276 C_{e}}{1+0.596 C_{e}}$

The Langmuir isotherm is plotted in Fig. 11. The adsorption capacity of mixed plastic char for COD was observed to be quite promising in the range of $1.45 .5-1.75 \mathrm{mg} / \mathrm{gm}$ 


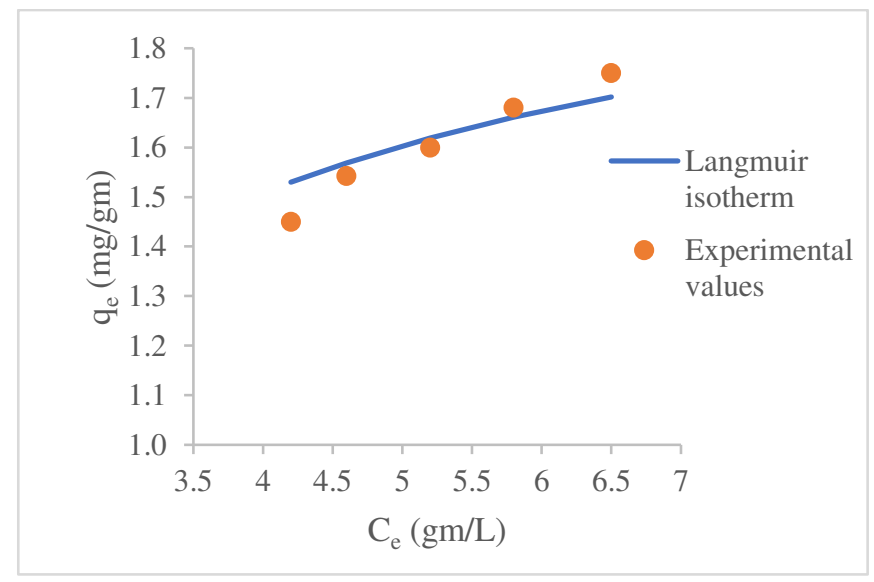

Fig. 11: Langmuir isotherm for $\mathrm{As}^{5+}$ adsorption onto mixed waste plastic (HDPE and PP) pyrolysis char

The pyrolytic char of mixed waste plastic was also tested for removal of COD from wastewater. The char obtained from $500{ }^{\circ} \mathrm{C}$ (P3) was used at a dose of $4 \mathrm{gm} / \mathrm{L}$. Rasheed et al. (2017) observed the removal of organic matter when char and biochar were used for wastewater treatment. Several studies were also conducted for wastewater treatment by using biochar (Lewis et al., 1995; Manyuchi et al., 2018; Yaseen et al., 2019). In the present study, the kitchen wastewater was taken from NIT Sikkim hostels, and after adsorption in a batch process, $\mathrm{pH}$ and COD were measured at different contact times (05-35 min). The raw wastewater $\mathrm{pH}$ and COD were found to be 7.4 and $485 \mathrm{mg} / \mathrm{L}$, respectively. The removal of COD steadily increased with increasing contact time till 25 min, beyond which no further increase in removal was observed (Fig. 12). The isotherm adsorption study was conducted with contact time of $25 \mathrm{~min}$ (equilibrium time) with varying doses of char from 2 to $4.0 \mathrm{gm} / \mathrm{L}$ (Fig. 13). It was observed with the increase of char dose, the COD removal increased significantly. Maximum 50\% removal of COD was observed at a dose of $4 \mathrm{gm} / \mathrm{L}$. Langmuir and Freundlich isotherm models were applied to the isotherm sorption data. The experimental data fitted better with Langmuir isotherm model $\left(\mathrm{R}^{2}=0.91\right)$ and was observed not to fit with Freundlich isotherm model $\left(\mathrm{R}^{2}=0.562\right)$ (Fig. 14 and Fig. 15).

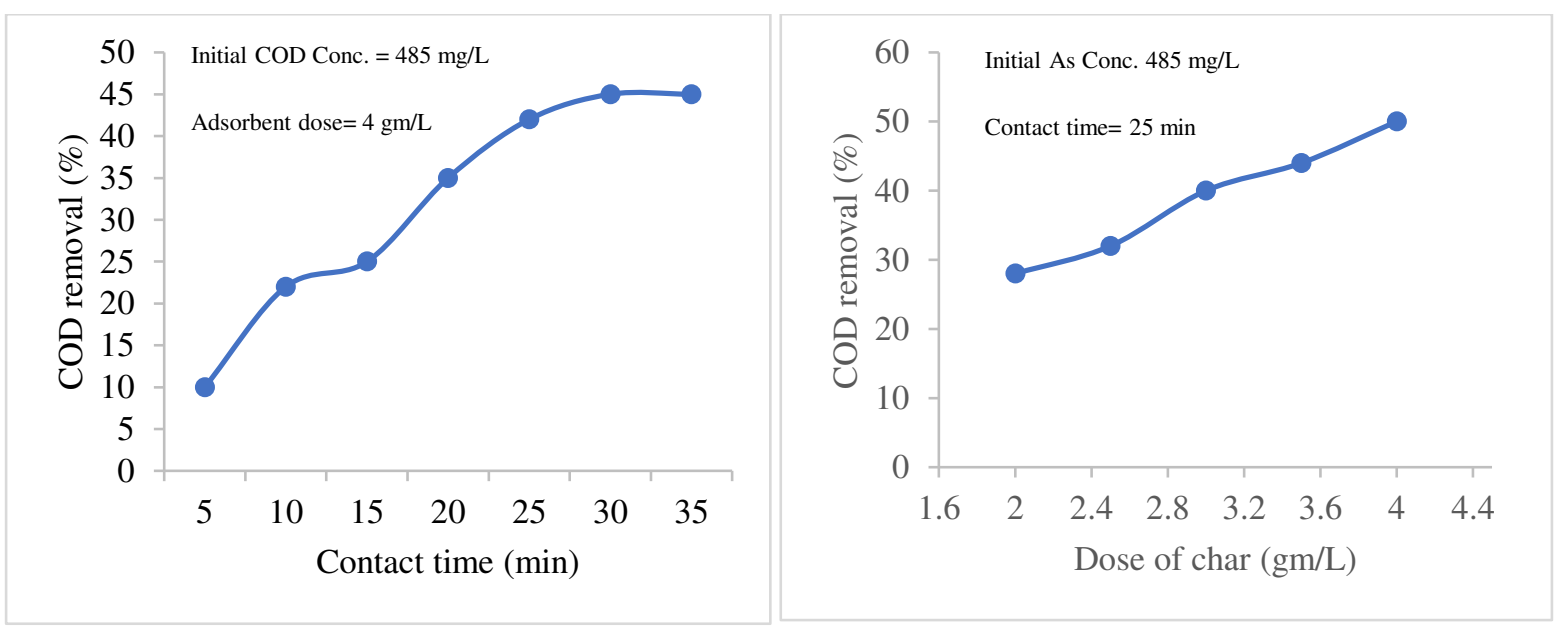

Fig. 12: Removal of COD for varying contact time

Fig. 13: Removal of COD for varying doses of char 


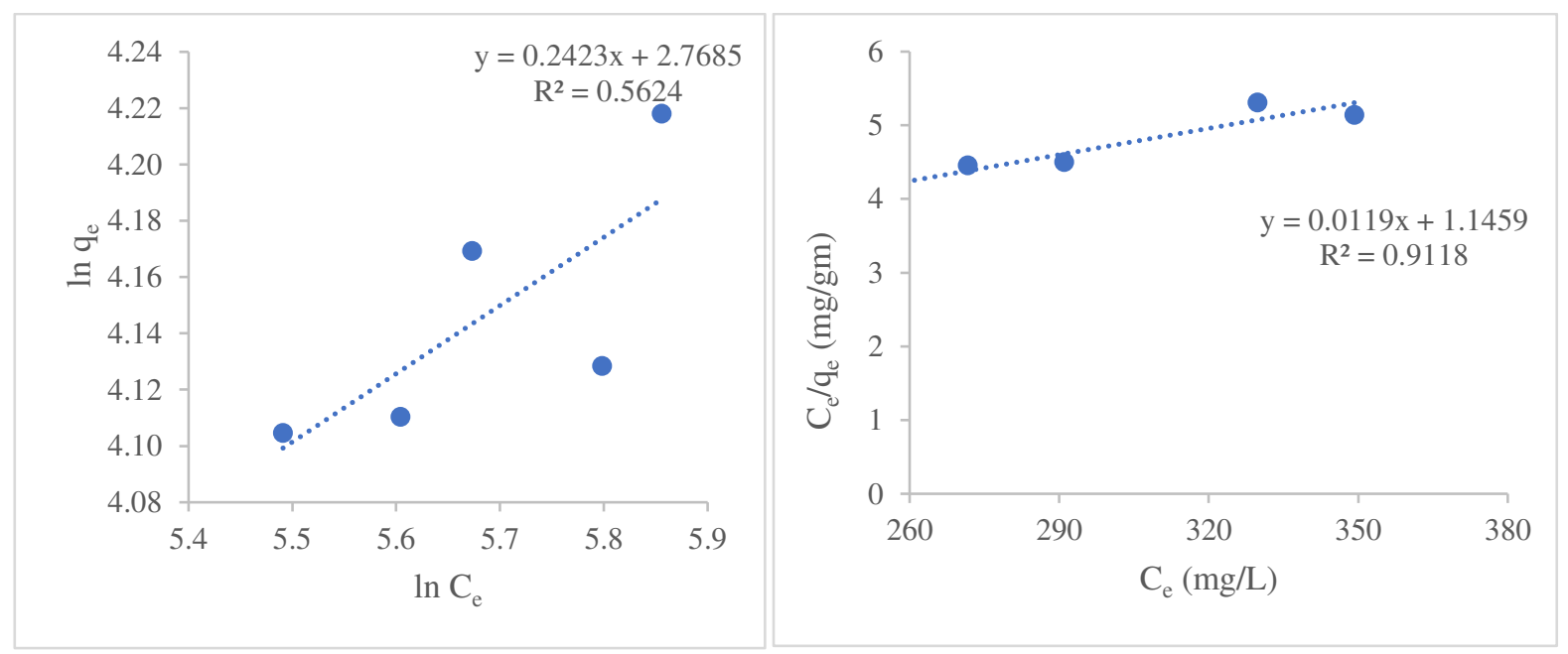

Fig. 14: Linearized Freundlich isotherm for COD removal Fig. 15: Linearized Langmuir isotherm for COD removal

From the linearized plot of Langmuir isotherm, $\mathrm{K}_{\mathrm{a}}$ and $\mathrm{q}_{\mathrm{m}}$ values were found 0.01 and 84.03, respectively.

Therefore, the Langmuir isotherm equation can be expressed as:

$\mathrm{q}_{\mathrm{e}}=\frac{0.8403 C_{e}}{1+0.01 C_{e}}$

The Langmuir isotherm is plotted in Fig. 16.

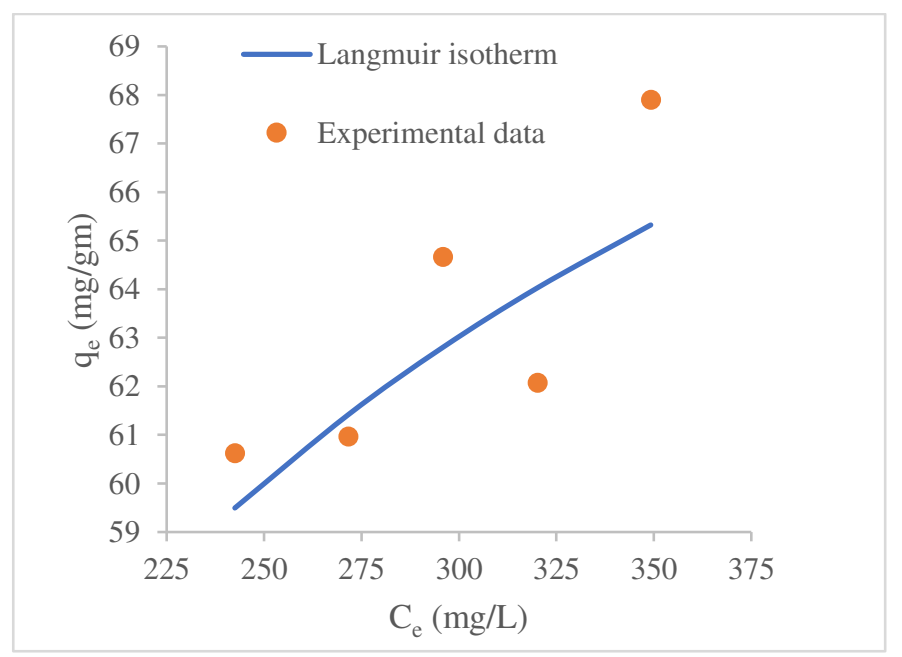

Fig. 16: Langmuir isotherm for COD removal onto mixed waste plastic (HDPE and PP) pyrolysis char

The adsorption capacity of mixed plastic char for COD was observed to be quite promising in the range of 60.62567.9 mg/gm (Fig. 16).

The char should also be tested with arsenic-contaminated natural water samples in both batch and column studies to ascertain its effectiveness as an adsorbent for practical applications. Similarly, column studies with wastewater samples for removal or COD would be necessary to evaluate char as an effective adsorbent for practical applications of wastewater treatment.

The As sorption and COD removal experiments were statistically analyzed using Analysis of Variance (ANOVA). ANOVA was applied to examine the hypothesis regarding the need for the char dose applied and to confirm the sorption capacity of different plastic char. The study analyzed the influence of independent variables (applied char dose) on dependent variables (As or COD sorption). p-values were used to denote statistically significant values. The level of significance was set at $\mathrm{p}<0.05$. For As removal, the value of $\mathrm{F}$ for a single way adopted was 
found to be 26.555, which is greater than the F critical value of 5.987. This confirmed that the null hypothesis is rejected with a 95 percent confidence level. Similarly, For COD removal, the value of F for a single way adopted was found to be 145.7, which is greater than the $\mathrm{F}$ critical value of 5.32. This confirmed that the null hypothesis is rejected with a 95 percent confidence level and therefore, the applied dose char has a major influence on the adsorption process.

\section{Conclusion}

Batch sorption experiments were used to explore the effect of plastic char on As and COD removal. Pyrolysis temperature has been found to be the most effective factor in controlling the surface properties of samples. It was found that with the increase of pyrolysis temperature $\left(400\right.$ to $\left.500{ }^{\circ} \mathrm{C}\right)$, the pore size of solid char increased (4.74.9 to $6-6.5 \mathrm{~nm}$ ). The solid char obtained from the waste plastic pyrolysis at $500{ }^{\circ} \mathrm{C}$ was found to have a density of $1.55-1.60 \mathrm{gm} / \mathrm{m}^{3}$ with BET surface area $10.5-12.8 \mathrm{~m}^{2} / \mathrm{gm}$. The plastic char samples showed significant changes in the structure when it was prepared at different temperatures $\left(400\right.$ to $500{ }^{\circ} \mathrm{C}$ ). It was noticed that the surface texture of char became rougher and more porous when either the operating temperature or the residence time (25 $\mathrm{min}$ to $35 \mathrm{~min}$ ) was increased. The XRD pattern of the plastic chars (S1, S2, \& S3) obtained in this study presented sharp diffraction crystalline peaks. Higher counts of peak in XRD of solid char at higher temperatures indicated increased crystallinity of char with increase of pyrolysis temperature. FTIR analysis was applied to characterize the various functional elements present in plastic char. The highest peak was observed at $717.39 \mathrm{~cm}^{-1}$. Carboxylic groups and lactones were identified from the FTIR spectra of the char. The solid char was tested for removal (adsorption) of inorganic $\left(\mathrm{As}^{5+}\right.$ ) and organic matters (COD) from water and wastewater, respectively. It was observed that the solid char could remove $60 \%$ of arsenic (+5) from an aqueous solution at a dose of $4 \mathrm{gm} / \mathrm{L}$ for a contact time of $30 \mathrm{~min}$. The COD removal was $50 \%$ at a dose of $4 \mathrm{gm} / \mathrm{L}$ with a contact time of $25 \mathrm{~min}$ and the adsorption data was found to fit better with Langmuir model. The adsorption capacity of mixed plastic char for $\mathrm{As}^{5+}$ was observed to be in the range of $1.45-1.75 \mathrm{mg} / \mathrm{gm}$ and in the range of $60.625-67.9 \mathrm{mg} / \mathrm{gm}$ for COD. Langmuir isotherm fitted well than Freundlich isotherm. The use of plastic char for the organic matter removal and inorganic components from water solutions demands further research for upscaling the technology more effectively for removal of other contaminants. The char should also be tested with arsenic-contaminated natural water samples in both batch and column studies to ascertain its effectiveness as an adsorbent for practical applications. Similarly, column studies with wastewater samples for removal or COD would be necessary to evaluate char as an effective adsorbent for practical applications of wastewater treatment.

\section{Acknowledgment}

The authors would like to thank the IIEST Shibpur and NIT Sikkim for the support provided for the work. The support and assistance provided by Mr. Suman Pathak, TA, Chemistry Laboratory, NIT Sikkim, is highly acknowledged. The authors are also thankful to all the researchers referred in the reference section for providing various relevant information for this research.

Funding: No funding was received to assist with the preparation of this manuscript.

Conflict of interest: The authors declare that they have no competing interests.

Data availability: The datasets generated during and/or analysed during the current study are available from the corresponding author on reasonable request.

\section{References}

1. Agrafioti E, Kalderis D, Diamadopoulos E (2014). Arsenic and chromium removal from water using biochars derived from rice husk, organic solid wastes and sewage sludge. Journal of Environmental Management, 133, 309-314. doi: 10.1016/j.jenvman.2013.12.007 
2. Alkurdi SSA, Al-Juboori RA, Bundschuh J, Bowtell L, McKnight S (2020). Effect of pyrolysis conditions on bone char characterization and its ability for arsenic and fluoride removal. Environmental Pollution, 262, 114221. doi:10.1016/j.envpol.2020.114221

3. Angın D, Şensöz S (2014). Effect of Pyrolysis Temperature on Chemical and Surface Properties of Biochar of Rapeseed (Brassica napusL.). International Journal of Phytoremediation, 16(7-8), 684-693. doi:10.1080/15226514.2013.856842

4. Anuar Sharuddin SD, Abnisa F, Wan Daud WMA, Aroua MK (2016). A review on pyrolysis of plastic wastes. Energy Conversion and Management, 115, 308-326. doi:10.1016/j.enconman.2016.02.03

5. Bilici Baskan M, Pala A (2011). Removal of arsenic from drinking water using modified natural zeolite. Desalination, 281, 396-403. doi:10.1016/j.desal.2011.08.015

6. Brunson LR, Sabatini DA (2015). Role of Surface Area and Surface Chemistry during an Investigation of Eucalyptus Wood Char for Fluoride Adsorption from Drinking Water. Journal of Environmental Engineering, 141(2), 04014060. doi:10.1061/(asce)ee.1943-7870.0000891

7. Claoston N, Samsuri A, Ahmad Husni M, Mohd Amran M (2014). Effects of pyrolysis temperature on the physicochemical properties of empty fruit bunch and rice husk biochars. Waste Management \& Research, 32(4), 331-339. doi:10.1177/0734242x14525822

8. Das B, Mondal NK (2011) Calcareous soil as a new adsorbent to remove lead from aqueous solution: equilibrium, kinetic and thermodynamic study. Universal J Environ Res Technol 1:515-530.

9. Devi R, Dahiya RP (2010). COD and BOD removal from domestic wastewater generated in decentralized sectors. Bioresour. Technol., 99, 344-349.

10. Djebaili K, Mekhalif Z, Boumaza A, Djelloul A (2015). XPS, FTIR, EDX, and XRD Analysis of $\mathrm{Al}_{2} \mathrm{O}_{3}$. Scales Grown on PM2000 Alloy. Journal of Spectroscopy, 2015, 1-16. doi:10.1155/2015/868109

11. Dutta N, Haldar A, Gupta A (2021). Electrocoagulation for Arsenic Removal: Field Trials in Rural West Bengal. Archives of Environmental Contamination and Toxicology, 80(1), 248-258. doi:10.1007/s00244020-00799-8

12. Dutta N, Gupta A (2021). An experimental study on conversion of high-density polyethylene and polypropylene to liquid fuel. Clean Technologies and Environmental Policy, 23(7), 2213-2220. doi:10.1007/s10098-021-02121-z

13. Fang J, Gao B, Zimmerman AR, Ro KS, Chen J (2016). Physically $\left(\mathrm{CO}_{2}\right)$ activated hydrochars from hickory and peanut hull: preparation, characterization, and sorption of methylene blue, lead, copper, and cadmium. RSC Advances, 6(30), 24906-24911. doi:10.1039/c6ra01644h

14. Fernandez Y, Arenillas A, Angel J (2011). Microwave Heating Applied to Pyrolysis. Advances in Induction and Microwave Heating of Mineral and Organic Materials. doi:10.5772/13548

15. Goswami D, Das AK (2000). Removal of arsenic from drinking water using modified fly-ash bed. International Journal of Water, 1(1), 61. doi:10.1504/ijw.2000.002053

16. Hong YS, Song KH, Chung JY (2014). Health Effects of Chronic Arsenic Exposure. Journal of Preventive Medicine and Public Health, 47(5), 245-252. doi:10.3961/jpmph.14.035.

17. Hossain AK, Davies PA (2013). Pyrolysis liquids and gases as alternative fuels in internal combustion engines - A review. Renewable and Sustainable Energy Reviews, 21, 165-189. doi:10.1016/j.rser.2012.12.031

18. Hata M, Amano Y, Thiravetyan P, Machida M (2016). Preparation of Bamboo Chars and Bamboo Activated Carbons to Remove Color and COD from Ink Wastewater. Water Environment Research, 88(1), 87-96. doi: $10.2175 / 106143015 \times 14362865227$

19. Hoslett J, Ghazal H, Ahmad D, Jouhara H (2019). Removal of copper ions from aqueous solution using low temperature biochar derived from the pyrolysis of municipal solid waste. Science of The Total Environment. doi:10.1016/j.scitotenv.2019.04.0

20. Jamradloedluk J, Lertsatitthanakorn C (2014). Characterization and Utilization of Char Derived from Fast Pyrolysis of Plastic Wastes. Procedia Engineering, 69, 1437-1442. doi:10.1016/j.proeng.2014.03.139

21. Jung SH, Cho MH, Kang BS, Kim JS (2010). Pyrolysis of a fraction of waste polypropylene and polyethylene for the recovery of BTX aromatics using a fluidized bed reactor. Fuel Processing Technology, 91(3), 277284. doi:10.1016/j.fuproc.2009.10.009

22. Subramanian KS, Viraraghavan T, Phommavong T, Tanjore S (1997). Manganese Greensand for Removal of Arsenic in Drinking Water. Water Quality Research Journal, 32(3), 551-562. doi:10.2166/wqrj.1997.032 
23. Kim Y, Kim C, Choi I, Rengaraj S, Yi J (2004). Arsenic Removal Using Mesoporous Alumina Prepared via a Templating Method. Environmental Science \& Technology, 38(3), 924-931. doi:10.1021/es0346431

24. Kobya M, Demirbas E, Gebologlu U, Oncel MS, Yildirim Y (2013). Optimization of arsenic removal from drinking water by electrocoagulation batch process using response surface methodology. Desalination and Water Treatment, 51(34-36), 6676-6687. doi:10.1080/19443994.2013.769700

25. Kumar S, Singh RK (2013). Thermolysis of High-Density Polyethylene to Petroleum Products. Journal of Petroleum Engineering, 2013, 1-7. doi:10.1155/2013/987568

26. Martín-Lara, MA., Piñar A, Ligero A, Blázquez G, Calero, M. (2021). Characterization and Use of Char Produced from Pyrolysis of Post-Consumer Mixed Plastic Waste. Water, 13(9), 1188. doi:10.3390/w13091188

27. Müller RJ, Kleeberg I, Deckwer WD (2001) Biodegradation of polyesters containing aromatic constituents. J. Biotechnol. 2001, 86, 87-95.

28. Nidheesh PV, Singh TSA (2017). Arsenic removal by electrocoagulation process: Recent trends and removal mechanism. Chemosphere, 181, 418-432. doi:10.1016/j.chemosphere.2017.04

29. Martín-Lara MA, Piñar A, Ligero A, Blázquez G, Calero M (2021). Characterization and Use of Char Produced from Pyrolysis of Post-Consumer Mixed Plastic Waste. Water, 13(9), 1188. doi:10.3390/w13091188

30. Mohan D, Pittman CU (2007). Arsenic removal from water/wastewater using adsorbents-A critical review. Journal of Hazardous Materials, 142(1-2), 1-53. doi:10.1016/j.jhazmat.2007.01.006

31. Khurshid H, Mustafa MRU, Rashid U, Isa MH, Ho YC, Shah MM (2021). Adsorptive removal of COD from produced water using tea waste biochar. Environmental Technology \& Innovation, 23, 101563. doi:10.1016/j.eti.2021.101563

32. Kumar A, Joseph S, Tsechansky L, Privat K, Schreiter IJ, Schüth C, Graber ER (2018). Biochar aging in contaminated soil promotes $\mathrm{Zn}$ immobilization due to changes in biochar surface structural and chemical properties. Science of The Total Environment, 626, 953-961. doi:10.1016/j.scitotenv.2018.01.1

33. Parande AK, Sivashanmugam A, Beluah H, Palaniswamy N (2009). Performance evaluation of low cost adsorbents in reduction of COD in sugar industrial effluent. J. Hazard. Mater., 168, 800-805.

34. Pereira APDS, Silva MHPD, Lima JÉP, Paula, ADS, Tommasini FJ (2017). Processing and Characterization of PET Composites Reinforced With Geopolymer Concrete Waste. Materials Research, 20(suppl 2), 411420. doi:10.1590/1980-5373-mr-2017-0734

35. Raessler M (2018). The Arsenic Contamination of Drinking and Groundwaters in Bangladesh: Featuring Biogeochemical Aspects and Implications on Public Health. Archives of Environmental Contamination and Toxicology, 75(1), 1-7. doi:10.1007/s00244-018-0511-4

36. Rani R, Juwarkar A (2009). Adsorption of Phorate, an Organophosphorus Pesticide, on Vertisol. Archives of Environmental Contamination and Toxicology, 58(4), 927-934. doi:10.1007/s00244-009-9424-6

37. Rahdar S, Taghavi M, Khaksefidi R, Ahmadi S (2019). Adsorption of arsenic (V) from aqueous solution using modified saxaul ash: isotherm and thermodynamic study. Applied Water Science, 9(4). doi:10.1007/s13201-019-0974-0

38. Rajesh Kannan R, Rajasimman M, Rajamohan N, Sivaprakash B (2010) Equilibrium and kinetic studies on sorption of malachite green using hydrilla Verticillata biomass. Int J Environ Res 4:817-824. doi: 10.22059/IJER.2010.268

39. Rojas-Mayorga CK, Bonilla-Petriciolet A, Aguayo-Villarreal IA, Hernández-Montoya V, Moreno-Virgen MR, Tovar-Gómez R, Montes-Morán MA (2013). Optimization of pyrolysis conditions and adsorption properties of bone char for fluoride removal from water. Journal of Analytical and Applied Pyrolysis, 104, 10-18. doi:10.1016/j.jaap.2013.09.018

40. Sanou Y, Pare S, Baba G, Segbeaya NK, Bonzi-Coulibaly LY (2016). Removal of COD in wastewaters by activated charcoal from rice husk. Revue Des Sciences de L'eau, 29(3), 265. doi:10.7202/1038927ar

41. Sathish MN, Jeyasanta I, Patterson J (2020). Microplastics in Salt of Tuticorin, Southeast Coast of India. Archives of Environmental Contamination and Toxicology. doi:10.1007/s00244-020-00731-0

42. Shaji E, Santosh M, Sarath KV, Prakash P, Deepchand V, Divya BV (2020). Arsenic contamination of groundwater: A global synopsis with focus on the Indian Peninsula. Geoscience Frontiers. doi:10.1016/j.gsf.2020.08.015. 
43. Shen T, Tang Y, Lu, XY, Meng Z (2018). Mechanisms of copper stabilization by mineral constituents in sewage sludge biochar. Journal of Cleaner Production, 193, 185-193. doi:10.1016/j.jclepro.2018.05.071

44. Singh E, Kumar A, Khapre A, Saikia P, Shukla, SK, Kumar S (2020). Efficient removal of arsenic using plastic waste char: Prevailing mechanism and sorption performance. Journal of Water Process Engineering, 33, 101095. doi:10.1016/j.jwpe.2019.101095.

45. Sobko AA (2008). Generalized van der Waals-Berthelot equation of state. Doklady Physics, 53(8), 416-419. doi:10.1134/s1028335808080028

46. Subramanian KS, Viraraghavan T, Phommavong T, Tanjore S (1997). Manganese Greensand for Removal of Arsenic in Drinking Water. Water Quality Research Journal, 32(3), 551-562. doi:10.2166/wqrj.1997.032

47. Sumathi T, Alagumuthu G (2014). Adsorption Studies for Arsenic Removal Using Activated Moringa oleifera. International Journal of Chemical Engineering, 2014, 1-6. doi:10.1155/2014/430417

48. Sun Y, Gao B, Yao Y, Fang J, Zhang M, Zhou Y, ... Yang L (2014). Effects of feedstock type, production method, and pyrolysis temperature on biochar and hydrochar properties. Chemical Engineering Journal, 240, 574-578. doi:10.1016/j.cej.2013.10.081

49. Tang Y, Alam MS, Konhauser, KO, Alessi DS, Xu S, Tian W, Liu Y (2018). Influence of pyrolysis temperature on production of digested sludge biochar and its application for ammonium removal from municipal wastewater. Journal of Cleaner Production. doi:10.1016/j.jclepro.2018.10.268

50. Tansel B, Yildiz BS (2011) Goal-based waste management strategy to reduce persistence of contaminants in leachate at municipal solid waste landfills. Environ. Dev. Sustain. 13, 821-831.

51. UNEP (2021). https://www.unep.org/interactive/beat-plastic-pollution/

52. WHO (2021). https://www.who.int/india/health-topics/arsenic (Accessed on 16.11.2021)

53. Xu Y, Nakajima T, Ohki A (2002). Adsorption and removal of arsenic(V) from drinking water by aluminumloaded Shirasu-zeolite. Journal of Hazardous Materials, 92(3), 275-287. doi:10.1016/s0304-3894(02)000201

54. Yoshitake H, Yokoi T, Tatsumi T (2003). Adsorption Behavior of Arsenate at Transition Metal Cations Captured by Amino-Functionalized Mesoporous Silicas. Chemistry of Materials, 15(8), 1713-1721. doi:10.1021/cm0218007

55. Zhao H, Song F, Su F, Shen Y, Li P (2020). Removal of Cadmium from Contaminated Groundwater Using a Novel Silicon/Aluminum Nanomaterial: An Experimental Study. Archives of Environmental Contamination and Toxicology. doi:10.1007/s00244-020-00784-1 